\title{
THE NEW OHIO GENERAL CORPORATION ACT
}

Ohio has enacted a new General Corporation Act, $^{1}$ in the preparation of which such unusual pains have been taken and so many experts consulted, and which is also so modern and complete that every person interested in corporation law should study it. The $A c t$ is more than a codification of existing law in one state; it reaches into fields where legislators and courts have so far only felt their way; it contains innovations; and it deserves a treatise. In this note, however, space and time allow mention only of some of its more interesting features.

Of these, perhaps the most striking is the careful adjustment of the institution of stock having no par value, allowed by the Act, to proper accounting and financing. Every corporation must have and carry on its books a "stated capital" (Section 37), which in the case of stock without par value includes the consideration received for its outstanding shares and its treasury shares. This "stated capital" is as public, as easy to ascertain by all concerned, and as important as a measuring rod to determine shareholders' obligations, the right to declare dividends, directors' liability, etc., as "capital stock," that is, number of shares multiplied by par value of each, used to be in days before no par stock (Sections $4,37,38,39,63,124$ ). Stock without par value cannot be carried on the books in such a way as to conceal or exaggerate the initial investment. ${ }^{2}$ In this same connection the Act adopts and enacts sound accounting principles. ${ }^{3}$ For example, the problem of determining whether a dividend is or is not payable does not turn on judicial interpretation of indeterminate words such as "surplus" and "profits"; instead, the Act prescribes in effect the items to be included in the corporate balance sheet,

\footnotetext{
1 "An act to revise, consolidate and codify the general corporation laws of Ohio and to repeal certain sections of the General Code," passed by Ohio General Assembly, February I6, 1927, approved March 8, 1927, effective June 9, I927.

${ }^{2} C f$. Willian Z. Ripley, Main Street to Wall Street (I927) 47, 197. sim.

${ }^{3}$ Cf. Prosper Retter, JR., Profits, Dividends and the Law (1926), pas-
} 
and these must be taken care of by the directors (Section $3^{8}$ ). To illustrate: allowance must be made for depreciation and depletion, ${ }^{4}$ deferred assets and prepaid expenses must be written off from time to time, unrealized appreciations based on revaluations cannot be made the basis for cash dividends, surplus arising or created in this way must be carried on the books separate from surplus profits and paid-in surplus (see Section 23), and books showing these facts are open to inspection by shareholders (Section 63; see Section 64). Some business men may feel that a corporation competing with rivals is made to give away too much, but from the shareholder's point of view this is admirable.

In another respect the Act favors shareholders more, perhaps, than is usual. A creditor who seeks to charge a shareholder for stock issued at an overvaluation must "affirmatively prove by clear and convincing evidence, and otherwise than by proving the difference between the value of such considerations and the amount so determined, that such determination of value was knowingly and intentionally made and fixed at an amount known to the parties making the same to be greater than the fair value of such considerations to the corporation." (Section 25.) "Determinations" will ordinarily be made by directors and must be entered on the books of account. The "consideration" in the case of shares with par value is the par value (Section I6), and in the case of shares without par value is as specified in the articles, or if not there specified, as determined by the shareholders concerned, or by the directors if so authorized by the Articles or by the shareholders (Section I7). If, however, the shareholder is liable, he is liable to the corporation (Sections 22, 24 ), and an individual creditor may proceed by a bill to reach and apply (Section 28 ). In brief, his liability is not entirely predicated on a theory of "holding out" nor on the "trust fund theory,"

"A corporation may be a "wasting assets" corporation only if so stated in its Articles (Section 38, ad fin.). See also The Rights of Stockholders Preferred as to Capital to Safeguard Their Interests in a Corporation, 75 U. of PA. L. REV. 350 (Ig27).

The rule of Handley v. Stutz, I39 U. S. 4 I7 (I89r), is enacted in this section in a broadened form. Any corporation more than two years old may issue par shares at less than par if the directors find shares cannot be sold at par and give shareholders a preêmptive right. 
but borrows from both, is sui generis, and seems easy of application with no unexpected pitfalls either for shareholder or creditor.

On the other hand the provisions of the Act as to the socalled preemptive right seem unfortunate from the point of view of the shareholder. Section 35 declares in effect that the holders of shares of any class have the right upon the sale for cash of shares of the same class to purchase such shares in proportion to their respective holdings of shares of such class. The section then provides that the right shall not exist in certain situations. The propriety of some of these may perhaps be questioned, but there is no space to do so here. It is the main part of the section which principally calls for comment. It is submitted that the Act confuses two distinct sorts of harm that may be done to a shareholder, ${ }^{6}$ unduly and unreasonably limits his rights in connection with both, and also gives him a right when he does not need it. A shareholder with voting power is harmed by a new issue of shares with voting power when he is given no opportunity to subscribe and thereby to preserve his proportionate voting strength. A shareholder, with or without voting power, is also harmed when his financial interest in the corporation's assets or earning power is altered to his disadvantage by a new issue; nor in such case will an opportunity to subscribe wholly obviate the harm. Two hypothetical cases will show the difference between these two sorts of harm:

(I) A corporation with I000 authorized outstanding voting shares, par, book and market value all $\$$ roo, authorizes and issues I000 new voting shares, par value $\$$ Ioo, but deferred as to capital and dividends, and therefore of a different "class," without giving old shareholders an opportunity" to subscribe. $A$, owning Ioo shares of the old issue, had a Io per cent. voting strength in the affairs of the company before, and only a 5 per cent. voting strength after the new issue. The first of the two harms above

- This is shown by the fact that the drafters of the Act in their note to this section refer to 5 FLETCHer, CyC. OF PRIVATE CoRporations, $\S 3462$, relating mostly to the first sort of harm and to A. A. Berle, Jr., 25 Columbia L. REv. 43, 56 et seq. (I924), and Hodgman v. Atlantic Refining Co., 300 Fed. 590 (D. C. Del., I924), relating to the second. 
mentioned has been done him, but the new issue being of a different "class," the section gives him no rights. The consideration for the new issue is, of course, immaterial here.

(2) Suppose the old issue was of no par value, but otherwise the same and that the new was of 1000 non-voting shares, not deferred as to capital or dividends, also of no par value, and that the consideration was $\$ 50,000$. The first harm is not done $A$ but the second one is. Again the section gives $A$ no preëmptive right. The new issue being non-voting is of a different "class." Even if $A$ were given a preëmptive right, he would by subscribing at best merely minimize and not obviate his damage. ${ }^{7}$

A third situation illustrates the curious working of Section 35. Suppose the first issue were of non-voting shares, book, par, and market value $\$ 100$; and that the new issue, exactly similar, is sold at $\$$ roo without giving $A$ an opportunity to subscribe. The section gives him a preemptive right although no harm is done him.

Cases that might well be omitted are therefore included and cases that ought to be included or otherwise provided for are left out. This is partly because the preemptive right is limited to shares of the same class and partly because the second sort of harm is not wholly cured by giving a preemptive right. It ought to be obvious that classification of shares in connection with pref-

${ }^{7}$ A preëmptive right will not prevent $A$ 's transferring some of the value that his shares represent to new shareholders. If he transfers this value to himself (as will happen only when he is allowed to and does subscribe to a proportion of the new issue equal to his proportion of the old), he may, it is true, maintain his proportionate financial interest in the corporation. But should he be required to pay money to protect himself? It may be granted that a shareholder who wishes to preserve his proportionate voting strength is only privileged to do so upon the payment of new money, but it is a different thing to make a man pay new money or else suffer a loss. The sort of case illustrated is likely to arise: (I) Where the new issue goes to an "insider" (see Hodgman v. Atlantic Refining Co., supra note 6, but cf., also, I3 F. (2d) 781 (C. C. A. 9th, 1926), in which case general principles may be sufficient to protect him (see A. A. Berle, Jr., 25 Columbia L. Rev. 43, 56, 60 (I924); 39 HARv. L. REv. 673 (1926); Bodell v. General Gas \& Electric Corp., I32 At1. 442 (Del. Ch. 1926), (2) Where there are issues of different classes with varying preferences. Under $\S I 6, A$ has, for what it is worth, a preemptive right as to new issues with par value, but only if they are sold for less than par. He does not have that right if the new issue is sold for par and is of a different class, even though his shares were worth per share more than par of the new issue. 
erences or deferments as to capital or dividends, etc., has nothing to do with the first sort of harm above mentioned provided both issues are of voting shares. If voting power is to be protected, all voting shares, subject to certain established restrictions more or less logical, ${ }^{8}$ should have a preemptive right in all new issues of voting shares whatever their class otherwise may be. The second sort of harm presents greater difficulties. The financial needs of the corporation as a whole are often such that a shareholder can fairly be called upon to endure a certain diminution in his financial interest. He must make a sacrifice in order to draw in new capital. All new issues, however, ought to be reasonable not only with regard to their effect on the corporation as a whole but with regard to their particular effect upon each previous issue. The Act is not wholly silent on this subject. For example, ${ }^{9}$ in connection with non-par shares, a corporation may peddle out such shares, even of the same class, for different considerations, provided that if the shares are of the same class shares issued at the same time must be issued for the same consideration; but even though this may be done in a fashion that alters a shareholder's financial interest very much to his disadvantage, nevertheless the shareholder is not without some protection in advance. Unless the Articles vest power in the directors, the consideration for the new issue must be fixed by the affirmative vote of a majority of the outstanding shares of the class to be issued and of junior classes, irrespective of voting power (Section $\mathrm{r} 7$ ). Is this protection sufficient, particularly in cases where the Articles vest in the directors power to fix the consideration for new issues? The argument that the shareholder, having bought shares in a corporation where the directors have power to alter the value of his investment, must take his medicine does not appeal to the writer of this note at any rate. If those who fix the value of the consideration have an unimpeachable discretion, the shareholder ought at least to have the right to have his shares bought by the corporation at their value before the new issue was

\footnotetext{
${ }^{8}$ As, for example, when the new issue is transferred for property.

- As to shares with par value, the consideration must be at par or more except as stated in note 5 supra. See note 7 supra.
} 
consummated. He has a right to compel the corporation to buy him out in some cases but not in this one (Section 72). ${ }^{10}$ If the discretion of shareholders and directors is impeachable on the ground of unfair discrimination against particular issues, the Act might well have said so and not have left it to possible inference. ${ }^{11}$

This is the only matter in which the writer feels moved to waste his eloquence in adverse citicism. The Act as a whole and in its many parts is so admirable that he is disarmed.

The part of the Act most likely to excite comment deals boldly with the vexed problem of ultra vires acts. "No limitation on the exercise of the authority of the corporation shall be asserted in any action between the corporation and any person, except by or on behalf of the corporation against a director or an officer or a person having actual knowledge of such limitation" (Section 8). Nor is any person charged with constructive notice of limitations on its authority appearing in its articles (Section 9). The drafters of the Act state largely that this "expresses the best business and legal thought" . . . and "makes the law of corporate power definite, direct and certain, obviating a disgraceful legal situation which had no basis in history, came into the law by mistake, and remained to plague business men and lawyers for nearly a hundred years." 12

When the section comes up for interpretation in court, it may be hoped that the phrase "authority of the corporation" will not be construed to cover also "authority of the agents of the corporation." Otherwise a corporation (and therefore its shareholders) will have less protection than the ordinary principal when his agent acts in an unauthorized manner. There also arises some question as to whether directors are ever agents who

${ }^{10}$ If the discrimination is effected by amendments to the Articles inserting new prior issues ahead of that of an objecting shareholder, he may compel the corporation to purchase his shares at their old value $(\$ \S 15,72)$.

${ }^{11} \mathrm{It}$ is suggested that a court might justify issues because reasonable as to the corporation as a whole but not reasonable in their application to particular groups of shareholders. Again, an Ohio Court, because of the completeness of the Act might find an intent therein not to give any additional remedy based on the fiduciary duties of consideration fixing agencies. See Bodell v. General Gas \& Electric Corporation, I32 Atl. 442 (Del. Ch. I926); Berle, op. cit. supra.

${ }^{12}$ See Ulira Vires as a Defense to Executory Contract Made by Corporation in Violation of Statutory Prohibition, 75 U. oF PA. L. REv. 454 (1927). 
can act outside the scope of their authority. All the capacity of a corporation and all its power and authority are vested in them, unless vested somewhere else by the Act or by the Articles (Section 55). Suppose the directors purport to do an act authority to do which is not vested in them. When will a corporation be liable? On this subject, so closely akin to the subject of true ultra vires and so often confused with it, the Act is silent.

It is somewhat to be regretted that the drafters did not choose to make the rules as to de facto corporations as "definite, direct and certain" as those relating to ultra vires acts. A copy of the articles filed in the proper place is only prima facie evidence of the existence of the corporation named therein (Section II7). Upon such filing corporate existence begins (Section 7), but does de jure existence begin when defective articles are filed?

There are many other features of the Act that repay study and justify comment, but neither time nor space permits their inclusion here.

Austin Tappan Wright.

University of Pennsylvania Law School. 